\title{
Comparative phylogeography of northwest African Natrix maura (Serpentes: Colubridae) inferred from mtDNA sequences
}

\author{
M. Barata', D.J. Harris ${ }^{1 *} \&$ R. Castilho \\ ${ }^{1}$ CIBIO, Centro de Investigação em Biodiversidade e Recursos Genéticos, Campus Agrário de Vairão, \\ 4485-661 Vairão, Portugal, and Departamento de Zoologia e Antropologia, Faculdada de Ciências, \\ Universidade do Porto, Praça Gomes Teixeira, 4099-002 Portugal \\ ${ }^{2}$ Center for Marine Sciences, (CCMAR), Campus de Gambelas - University of Algarve, \\ P-8005-139, Faro, Portugal \\ Received 16 April 2007. Accepted 31 July 2007
}

\begin{abstract}
While the comparative phylogeography of European fauna is relatively well understood, with Pleistocene climatic oscillations leading to 'southern refugia' for many species, the equivalent pattern has not been determined for North Africa. In this context variation within North African populations of the riverine snake Natrix maura were assessed using mitochondrial DNA sequences. Recent literature regarding North African phylogeographic studies of reptiles was compiled, and several surprising patterns emerged. The most interesting was the extensive movement of species across the Strait of Gibraltar during the Pleistocene. Another is the general pattern of deep genetic divergences between Tunisian and Moroccan populations, often at a level implying the existence of cryptic species. Natrix maura has three distinct lineages in North Africa, however, it apparently did not cross the Strait of Gibraltar during the Pleistocene, but probably did so during the Messinian salinity crisis.
\end{abstract}

Key words: Natrix maura, mitochondrial DNA, comparative phylogeography, northwest Africa.

\section{INTRODUCTION}

The role of Pleistocene climatic oscillations in shaping genetic diversity is well known, with 'southern refugia' harbouring much of the variation (Hewitt 2000). Studies within the Iberian Peninsula have largely supported this, with deeply divergent lineages reported within many reptile species such as Podarcis hispanica (Pinho et al. 2006), Blanus cinereus (Vaconcelos et al. 2006) and Lacerta schreiberi (Godinho et al. 2005), leading to the hypothesis of 'refugia within refugia' (Gomez \& Lunt 2006). In terms of phylogeography, species that occur in both the Iberian Peninsula and North Africa are of particular interest. During the Messinian period a land connection briefly linked these two areas across the Strait of Gibraltar (Duggen et al. 2003), allowing considerable faunal interchange. Since then the Mediterranean has continually separated Europe from North Africa, and most reviews of the post-glacial recolonization of Europe do not consider any role played by North African fauna (e.g. Hewitt 1999). Indeed, genetic variation across the Strait of Gibraltar has been used as a calibration for molecular clocks, assuming that diversification is a direct

\footnotetext{
*Author for correspondence: E-mail: james@mail.icav.up.pt
}

result of the opening of the Mediterranean, approximately 5.3 Mya (e.g. Sotiropoulos et al. 2007). Several studies of related Iberian and North African taxa do seem to support such a hypothesis, including one lineage of the $P$. hispanica complex (Pinho et al. 2006), Acanthodactylus erythrurus (Harris et al. 2004a) and Salamandra (Escoriza et al. 2006). However, other taxa crossed the narrow marine barrier, presumably by rafting, such as a different lineage of the P. hispanica complex (Pinho et al. 2006) and Psammodromus algirus (Carranza et al. 2006a). More surprisingly, many other species show almost no differentiation between northwest Africa and Iberia, indicating mid-Pliocene colonizations, possibly during glacial maxima when sea levels were lower. These include chameleons (Paulo et al. 2002), tortoises (Álvarez et al. 2000), the terrapin Mauremys (Fritz et al. 2006) and three snakes Macroprotodon (Carranza et al. 2004), Malpolon and Hemorrhois hippocrepis (Carranza et al. 2006b). Such studies indicate that analysis of North African taxa is necessary to better understand species distribution within Europe. They also show that widespread sampling is needed, or entire genetic lineages may go unreported. In North Africa deeply divergent genetic lineages, 


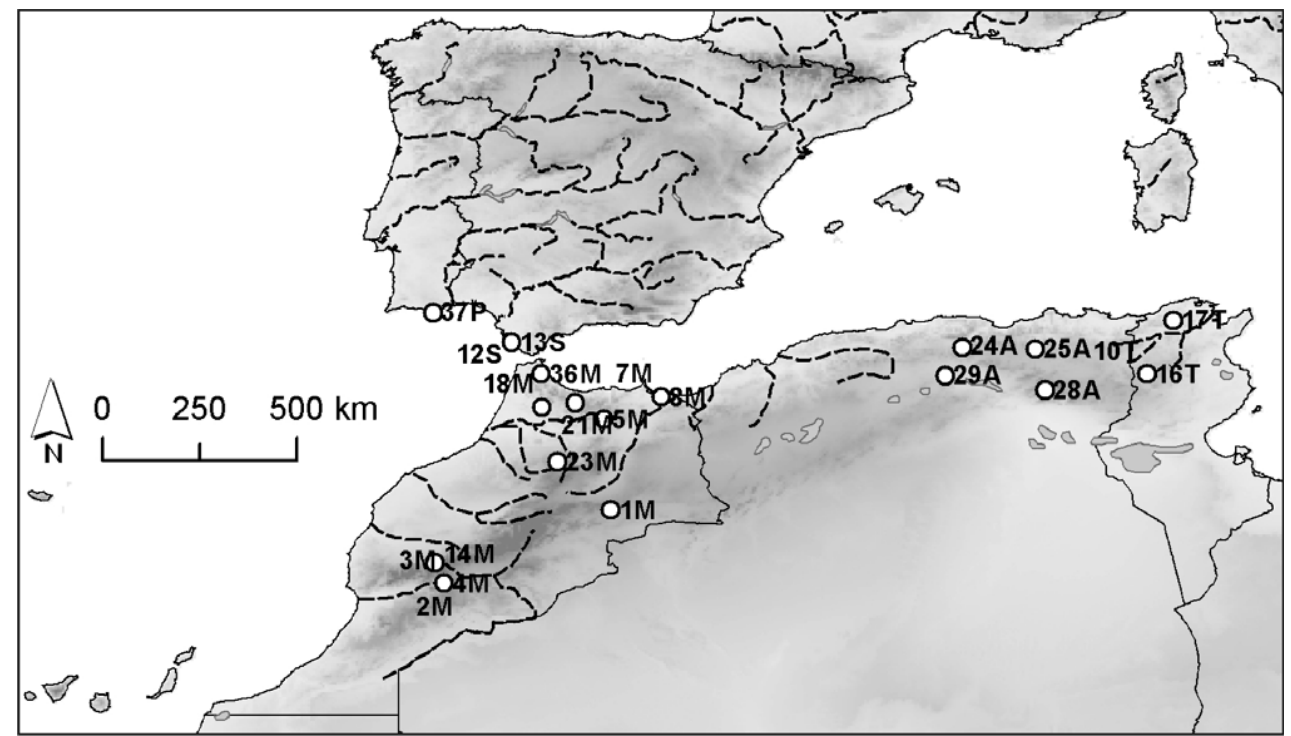

Fig. 1. Map showing sampling localities. Codes relate to Table 1 and Fig. 2. Major rivers are indicated with dashed lines.

possibly reflecting the existence of currently unrecognized species, have been reported in the lizards Lacerta perspicillata (Perera et al. 2007), Tarentola mauritanica (Harris et al. 2004b,c), Uromastyx (Harris et al. 2007), Podarcis hispanica (Pinho et al. 2006, 2007) and Agama (Brown et al. 2002). Deep divergences in the snakes Macroprotodon and Malpolon have also contributed to the recognition of multiple species within these groups in North Africa (Carranza et al. 2004, 2006b).

The viperine snake Natrix maura (Linnaeus, 1758 ) is widespread in Europe from Portugal and Spain through France to southwestern Switzerland and northwest Italy. In North Africa it occurs in much of Morocco, northern Algeria, northern Tunisia and northwest Libya. It is also present on several Mediterranean islands (Arnold 2002). A diurnal species, it is normally found close to or within water bodies such as streams or ponds. It has also been found in brackish water, and may therefore be a candidate for traversing narrow marine barriers. Guicking et al. (2002) reported three genetic lineages based on mtDNA; one in Europe, one in Morocco, and one in Tunisia and Sardinia. In an extension of this study Guicking et al. (2006) indicated that the Moroccan and European lineages are sister taxa $(96 \%$ Bayesian posterior probability). These authors use the Strait of Gibraltar as one of the calibration points to date a molecular clock, assuming European and Moroccan lineages separated 5.3 Mya.
The aim of this study was to extend the analysis of N. maura across more of its North African range. With greater sampling the chance of detecting signs of recent gene flow across the Strait, as seen in Malpolon and Macroprotodon, is increased. By including samples from across proposed geological barriers, such as the Atlas Mountains and the Moulouya river valley, the influence of these on population structure within N. maura can be assessed. Both could be barriers to gene flow in Natrix, the Atlas Mountains being inappropriate habitat except in some valleys, and the Moulouya River valley being an expansive arid zone that is presently too dry for Natrix except near the Mediterranean coast. Additionally, samples from Jebel Sirwah, at the extreme south of the range, and south of the High Atlas Mountains, were included. Podarcis lizards from this relatively isolated mountain are more similar to Tunisian than to other Moroccan populations (Harris et al. 2002; Pinho et al. 2003, 2006). Similarly in the terrapin Mauremys leprosa, specimens from south of the Atlas Mountains resemble eastern Algerian and Tunisian populations, but not other Moroccan populations (Fritz et al. 2006). Thus the generality of this biogeographic pattern can also be examined.

\section{METHODS}

Specimens were identified in the field following Arnold (2002), digital photographs taken, and a portion of tail removed and stored in 100\% ethanol 
Table 1. Specimens sequenced for this analysis, with locality data.

\begin{tabular}{lcl}
\hline Locality & Sample code & Coordinates \\
\hline Ait-lchchou, Morocco & $1 \mathrm{M}$ & $32^{\circ} 25^{\prime} \mathrm{N}, 3^{\circ} 46^{\prime} \mathrm{W}$ \\
Jebel Sirwah, Morocco & $2 \mathrm{M}$ & $30^{\circ} 43^{\prime} \mathrm{N}, 7^{\circ} 37^{\prime} \mathrm{W}$ \\
Jebel Sirwah, Morocco & $3 \mathrm{M}$ & $30^{\circ} 43^{\prime} \mathrm{N}, 7^{\circ} 37^{\prime} \mathrm{W}$ \\
Jebel Sirwah, Morocco & $4 \mathrm{M}$ & $30^{\circ} 43^{\prime} \mathrm{N}, 7^{\circ} 37^{\prime} \mathrm{W}$ \\
Taounate, Morocco & $5 \mathrm{M}$ & $34^{\circ} 31^{\prime} \mathrm{N}, 4^{\circ} 38^{\prime} \mathrm{W}$ \\
Mouth of river Moulouya, Morocco & $6 \mathrm{M}$ & $35^{\circ} 2^{\prime} 51^{\prime \prime} \mathrm{N}, 2^{\circ} 35^{\prime} 29^{\prime \prime} \mathrm{W}$ \\
Mouth of river Moulouya, Morocco & $7 \mathrm{M}$ & $35^{\circ} 2^{\prime} 51^{\prime \prime} \mathrm{N}, 2^{\circ} 35^{\prime} 29^{\prime \prime} \mathrm{W}$ \\
Mouth of river Moulouya, Morocco & $8 \mathrm{M}$ & $35^{\circ} 2^{\prime} 51^{\prime \prime} \mathrm{N}, 2^{\circ} 35^{\prime} 29^{\prime \prime} \mathrm{W}$ \\
Oukaimeden, High Atlas, Morocco & $14 \mathrm{M}$ & $31^{\circ} 12^{\prime} 21^{\prime \prime} \mathrm{N}, 7^{\circ} 50^{\prime} 51^{\prime \prime} \mathrm{W}$ \\
Zoumi, Morocco & $18 \mathrm{M}$ & $34^{\circ} 48^{\prime} 29^{\prime \prime} \mathrm{N}, 5^{\circ} 21^{\prime} 18^{\prime \prime} \mathrm{W}$ \\
Ketama, Morocco & $21 \mathrm{M}$ & $34^{\circ} 55^{\prime} 02^{\prime \prime} \mathrm{N}, 4^{\circ} 34^{\prime} 64^{\prime \prime} \mathrm{W}$ \\
Ifrane, Morocco & $23 \mathrm{M}$ & $33^{\circ} 32^{\prime} 70^{\prime \prime} \mathrm{N}, 5^{\circ} 0^{\prime} 03^{\prime \prime} \mathrm{W}$ \\
Sta Marta, Spain & $12 \mathrm{~S}$ & $36^{\circ} 28^{\prime} 01^{\prime \prime} \mathrm{N}, 4^{\circ} 59^{\prime} 20^{\prime \prime} \mathrm{W}$ \\
Sta Marta, Spain & $13 \mathrm{~S}$ & $36^{\circ} 28^{\prime} 01^{\prime \prime} \mathrm{N}, 4^{\circ} 59^{\prime} 20^{\prime \prime} \mathrm{W}$ \\
Thala, Tunisia & $10 \mathrm{~T}$ & $35^{\circ} 34^{\prime} 28^{\prime \prime} \mathrm{N}, 8^{\circ} 40^{\prime} 20^{\prime \prime} \mathrm{E}$ \\
Thala, Tunisia & $16 \mathrm{~T}$ & $35^{\circ} 34^{\prime} 28^{\prime \prime} \mathrm{N}, 8^{\circ} 40^{\prime} 20^{\prime \prime} \mathrm{E}$ \\
Jebel Zebla, Tunisia & $17 \mathrm{~T}$ & $36^{\circ} 49^{\prime} \mathrm{N}, 9^{\circ} 16^{\prime} \mathrm{E}$ \\
Bouira, Bordj bou Arreridj, Algeria & $24 \mathrm{~A}$ & $36^{\circ} 11^{\prime} 43^{\prime \prime} \mathrm{N}, 4^{\circ} 23^{\prime} 68^{\prime \prime} \mathrm{E}$ \\
Batna, Algeria & $25 \mathrm{~A}$ & $36^{\circ} 34^{\prime} 78^{\prime \prime} \mathrm{N}, 6^{\circ} 4^{\prime} 57^{\prime \prime} \mathrm{E}$ \\
Batna, Biska, Algeria & $28 \mathrm{~A}$ & $35^{\circ} 12^{\prime} 32^{\prime \prime} \mathrm{N}, 6^{\circ} 18^{\prime} 09^{\prime \prime} \mathrm{E}$ \\
Bou Saada, Sour el Ghozlane, Algeria & $29 \mathrm{~A}$ & $35^{\circ} 12^{\prime} 55^{\prime \prime} \mathrm{N}, 4^{\circ} 10^{\prime} 46^{\prime \prime} \mathrm{E}$ \\
Faro, Algarve, Portugal & $37 \mathrm{P}$ & $37^{\circ} 0^{\prime} 08^{\prime \prime} \mathrm{N}, 7^{\circ} 53^{\prime} 02^{\prime \prime} \mathrm{W}$ \\
\hline
\end{tabular}

(Fig. 1 and Table 1). Several specimens were road kills. All live specimens were released immediately after sampling. Total genomic DNA was extracted from these small pieces of tissue using standard methods (Sambrook et al. 1989). Polymerase Chain Reaction primers used in both amplification and sequencing were ND4L and ND4H (Arevalo et al. 1994), which amplify a portion of the mitochondrial ND4 gene. Amplified fragments were sequenced on a 310 Applied Biosystem DNA Sequencing Apparatus.

Sequences were trimmed so that all consisted of 654 base pairs. Mitochondrial DNA sequences were aligned using Clustal W (Thompson et al. 1994). Five specimens of Natrix maura that were previously published on GenBank were included, as were single specimens of Natrix natrix and Natrix tessellata (all from Guicking et al. 2006) that were designated as outgroups following Guicking et al. (2006). New sequences were submitted to GenBank, accession numbers EU437551 to EU 437572.

The data were imported into PAUP* $4.0 \mathrm{~b} 10$ (Swofford 2002) for phylogenetic analysis. For the phylogenetic analysis of the mtDNA data maximum likelihood (ML), maximum parsimony (MP) and Bayesian inference were used. The approach outlined by Huelsenbeck \& Crandall (1997) was used to test 56 alternative models of evolution, employing PAUP* 4.0b10 and Modeltest (Posada \& Crandall 1998). Once a model of evolution was chosen using the AIC criteria, it was used to estimate a tree using ML with a 10 replicate heuristic search. The MP analysis was carried out with a 100 replicate heuristic search and TBR branch-swapping. In both cases support for nodes was estimated by bootstrapping with 1000 replicates (Felsenstein 1985). The Bayesian analysis was implemented using MrBayes version 2.01 (Huelsenbeck \& Ronquist 2001) which calculates Bayesian posterior probabilities using a Metropolis-coupled, Markov chain Monte Carlo (MC-MCMC) sampling approach. Bayesian analyses were conducted with random starting trees, run $1 \times 10^{6}$ generations, and sampled every 1000 generations using the general-time reversible model of evolution with a model of among-site rate variation. Two independent replicates were conducted and inspected for consistency to check for local optima (Huelsenbeck \& Bollback 2001). In both searches stationarity of the Markov chain was determined as the point when sampled log likelihood values plotted against generation time reached a stable mean equilibrium value; 'burn-in' data sampled from generations preceding this point were discarded. All data collected at stationarity were used to estimate posterior nodal probabilities and a summary phylogeny. 


\section{RESULTS \& DISCUSSION}

Including the outgroups, $31 \mathrm{mtDNA}$ sequences were analysed. It was concluded that the $\operatorname{TrN}$ model with an estimated proportion of invariable sites was the most appropriate model of evolution for these data. A 10 replicate heuristic search incorporating this model found one tree of $-\ln 1881$. Maximum parsimony analysis of 78 informative characters found eight trees of 212 steps, the 50\% bootstrap consensus of which was similar to the ML analysis, but differed in weakly supported nodes (Fig. 2). The Bayesian analysis produced a single estimate of relationships with an identical topology to ML.

Four genetically distinct units can be identified from these analyses, all of which are geographically coherent, although relationships between these units are not all well supported. As found in previous studies (Guicking et al. 2002, 2006), one lineage comprises all the European specimens. Within this lineage there is considerable substructuring, in particular between one sample from southern Spain (from Cadiz province) and the remaining European specimens (approximately $2.5 \%$ sequence divergence using the ML model). Such phylogeographic structuring fits with the refugia within refugia hypothesis (Gomez \& Lunt 2006). In other words, not only did the Iberian Peninsula act as a glacial refugia for many taxa during the last glacial period, but in many cases multiple distinct refugia were maintained. Multiple refugia have been inferred for many other reptile species, such as Lacerta schreiberi and the Podarcis hispanica species complex (Gomez \& Lunt 2006).

The remaining three lineages are all endemic to North Africa. One comprises samples from across Morocco west of the Moulouya River, including specimens from Jebel Sirwah in the Anti-Atlas. A second lineage comprises specimens from Tunisia and one from Eastern Algeria, while the third includes specimens from Central and Western Algeria and also a specimen from Morocco collected at the mouth of the Moulouya River. The latter two lineages are well supported as sistertaxa, and are the least divergent of the four main lineages $(2.8 \%)$. Both are approximately $4.5 \%$ divergent from the Moroccan lineage.

Within a comparative phylogeographic framework, several examples of concordance and discordance between studied North African reptiles can be seen. Of the snakes studied, Macroprotodon cucullatus, M. monspessulanus, Psammophis shokari and $N$. maura all show divergent lineages between the eastern and western Maghreb of northwest Africa (Carranza et al. 2004, 2006a; Rato et al. 2007 this study, respectively). Similar patterns are also seen in the amphisbaenian Trogonophis (Mendonça \& Harris 2007) and the lizard Tarentola (Harris et al. 2004). However, the geographic limitation of the divergent lineages is clearly different - in M. monspessulanus specimens from across Algeria are nested within the Moroccan lineage, and are highly divergent from Tunisian lineages (Carranza et al. 2006a). Only in N. maura does the Moulouya River valley approximately separate lineages. Perhaps more surprisingly, all of these snakes and also $H$. hippocrepis (Carranza et al. 2006a) show minimal genetic diversity across Morocco despite morphological variation in some species (such as the three morphs of $P$. shokariRato et al. 2007). The low levels of genetic variability within species across Northern Europe is typically linked to recent postglacial recolonizations of this area, with variation remaining in southern refugia (Hewitt 2000). Under such a scenario variation within species from Morocco would be expected to be high - indeed there is a strong north-south increase in genetic variation within forms of the wall lizards Podarcis across the Iberian Peninsula and North Africa (Pinho et al. 2007). High intraspecific variation within this region has also been reported in other reptiles, such as the lizards Acanthodactylus erythrurus (Harris et al. 2004a), A. pardalis (Fonseca et al. 2008) and Tarentola mauritanica (Harris et al. 2004b,c). Possibly in the smaller lizards, populations could survive in small, isolated patches of favourable habitat and these each evolved unique haplotypes that led to the considerable phylogeographic variation now observed. The snakes, however, required larger populations of prey to sustain viable populations and thus were limited to the very few large regions of appropriate habitat. From these they expanded rapidly after the last glacial maximum, and thus haplotypic variation is minimal.

Interestingly, M. monspessulanus, M. cucullatus and H. hippocrepis all have limited genetic differentiation between Iberian and Moroccan populations, implying a recent crossing from North Africa to Iberia. Natrix maura, however, shows no evidence of such an event. Greater sampling in southern Iberia will be needed to confirm this. Several other reptiles also show a similar phylogeographic pattern, including chameleons (Paulo et al. 2002), terrapins (Fritz et al. 2006), tortoises (Álvarez et al. 2000) and Blanus worm lizards (Vasconcelos et al. 


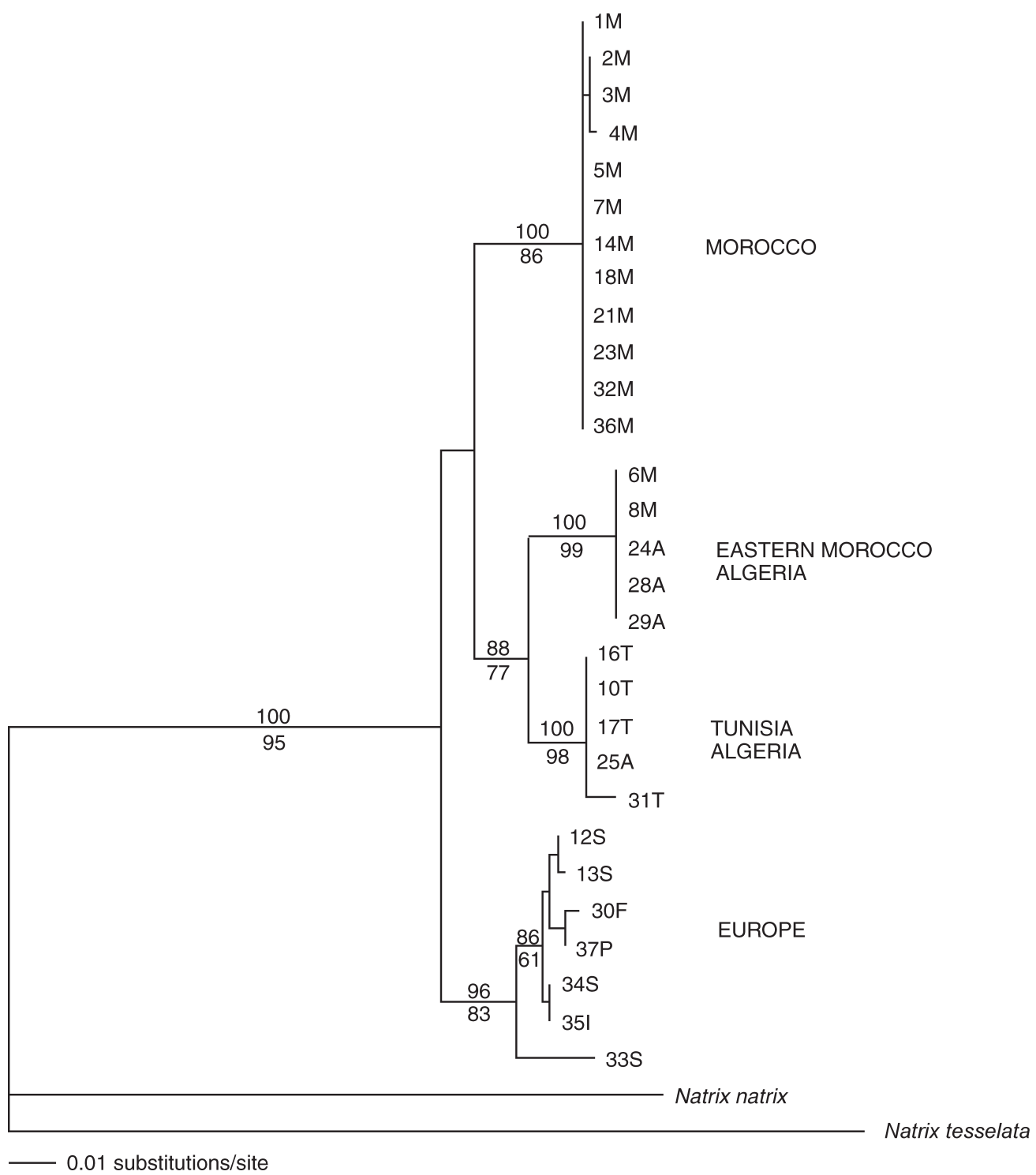

Fig. 2. Single tree derived from a ML analysis using the model described in the text. Bootstrap values for MP and ML are given below and above the respective nodes. All nodes with bootstrap support indicated had Bayesian posterior probabilities above $95 \%$. Codes relate to Table 1 and Fig. 1. The tree was rooted using Natrix natrix and Natrix tessellata.

2006). In isolation these could be assumed to be due to recent anthropogenic introductions, but such a high proportion of diverse species requires an alternative explanation. Possibly they all crossed naturally by 'hopping' across the Strait of Gibraltar via temporary islands that were exposed during sea-level falls associated with the last glacial period (Carranza et al. 2006). Thus the Iberian Peninsular diversity may be the result of a mixture of European and North African lineages, as well as due to its role as a 'southern refugium'. The importance of North Africa in the post-glacial repopulation of Europe clearly needs to be further assessed, not just for reptiles but for all widespread fauna and flora.

Pinho et al. (2006, 2007a,b) showed that the wall lizards, Podarcis, from Jebel Sirwah, an isolated mountain in Southern Morocco, were more closely related to Tunisian populations than to nearby Moroccan ones. Mauremys leprosa also has 
haplotypes in southern Morocco that are more closely related to eastern Algerian and Tunisian haplotypes (Fritz et al. 2006). A similar pattern is seen in A. erythrurus, in that the Jebel Sirwah population is genetically distinct from Moroccan populations, and for mtDNA at least, is more closely related to Algerian populations (Fonseca et al., unpubl.). However, in N. maura such a pattern is not recovered. The higher dispersal capability of N. maura may mean that the mountain of Jebel Sirwah is less isolated for this species. Analysis of other snakes and lizards from this area will be valuable in assessing the general biogeographic pattern of a link between the mountains of the Anti-Atlas of southern Morocco with Algeria and Tunisia.

\section{CONCLUSIONS}

Although clearly not as well studied as Europe, biogeographic patterns for the northwest African reptile fauna are beginning to take shape. The most important pattern is a high ratio of species spreading across the Strait of Gibraltar during the Pleistocene. Thus, to fully understand the postglacial recolonization of Europe, a more detailed assessment of variation within North Africa is needed. Whether or not a similar pattern also exists between North Africa and southern Italy remains to be verified. Almost every species examined in North Africa shows levels of intraspecific variation higher than expected relative to European taxa, supporting the hypothesis of a geopolitical bias affecting expectations of mtDNA variation found within species (Harris \& Froufe 2005). The Mediterranean Basin is an acknowledged hotspot for biodiversity (Myers et al. 2000), but this would imply that the importance of North Africa is even greater than that of the southern European peninsulas. A general pattern of high differentiation between Moroccan and Tunisian specimens is observed in many species, but sampling is typically limited in Algeria and therefore the exact ranges of these genetic lineages often remains unknown. Further lineages may be found as sampling is extended. This is the case for N. maura, with three distinct North African lineages.

\section{ACKNOWLEDGEMENTS}

This project was partially supported by a grant from Fundação para a Ciência e Tecnologia PTDC/BIA-BDE/74349/2006. Thanks to all our colleagues who assisted during fieldwork in North Africa, and to two anonymous reviewers for their constructive comments.

\section{REFERENCES}

ALVAREZ, Y., MATEO, J.A., ANDREU, A.C., DIAZ-PANIGUA, C., DIEZ, A. \& BAUTISTA, J.M. 2000. Mitochondrial DNA haplotyping of Testudo graeca on both continental sides of the Straits of Gibraltar. Journal of Heredity 91: 39-41.

ARÉVALO, E., DAVIS, S.K. \& SITES, J.W. 1994. Mitochondrial DNA sequence divergence and phylogenetic relationships among eight chromosome races of the Sceloporus grammicus complex (Phrynosomatidae) in central Mexico. Systematic Biology 43: 387-418.

ARNOLD, E.N. (2002) A Field Guide to the Reptiles and Amphibians of Britain and Europe. HarperCollins Publishers, London.

BALLARD, J.W.O. \& WHITLOCK, M.C. 2004. The incomplete history of mitochondria. Molecular Ecology 13: 729-744.

BROWN, R.P., SUARÉZ, N.M. \& PESTANO, J. 2002. The Atlas Mountains as a biogeographical divide in North-West Africa: evidence from mtDNA evolution in the Agamid lizard: Agama impalearis. Molecular Phylogenetics and Evolution 24: 324-332.

CARRANZA, S., ARNOLD, E.N., WADE, E. \& FAHD, S. 2004. Phylogeography of the false smooth snakes, Macroprotodon (Serpentes, Colubridae): mitochondrial DNA sequences show European populations arrived recently from Northwest Africa. Molecular Phylogenetics and Evolution 33: 523-532.

CARRANZA, S., ARNOLD, E.N. \& PLEGUEZUELOS, J.M. 2006. Phylogeny, biogeography and evolution of two Mediterranean snakes, Malpolon monspessulanus and Hemorrhois hippocrepis (Squamata, Colubridae) using mtDNA sequences. Molecular Phylogenetics and Evolution 40: 532-546.

CARRANZA, S., HARRIS, D.J., ARNOLD, E.N., BATISTA, V. \& GONZALEZ DE LA VEGA, J.P. 2006. Phylogeography of the lacertid lizard, Psammodromus algirus, in Iberia and across the Strait of Gibraltar. Journal of Biogeography 33: 1279-1288.

DUGGEN, S., HOERNLE, K., VAN DEN BOGAARD, P., RUPKE, L. \& MORGAN, J.P. 2003. Deep roots of the Messinian salinity crisis. Nature 422: 602-606.

ESCORIZA, D., COMAS, M.M., DONAIRE, D. \& CARRANZA, S. 2006. Rediscovery of Salamandra algira Bedriaga, 1833 from the Beni Snassen Massif (Morocco) and phylogenetic relationships of North African Salamandra. Amphibia-Reptilia 27: 448-455.

FELSENSTEIN, J. 1985. Confidence limits on phylogenies: an approach using the bootstrap. Evolution 39: 783-791.

FONSECA, M.M., BRITO, J.C., REBELO, H., KALBOUSSI, M., LARBES, S., CARRETERO, M.A. \& HARRIS, D.J. 2008. Genetic variation in the Acanthodactylus pardalis group in North Africa. African Zoology 43: 8-15.

FRITZ, U., BARATA, M., BUSACK, S.D., FRITSCH, G. \& CASTILHO, R. 2006. Impact of mountain chains, sea straits and peripheral populations on genetic and taxonomic structure of a freshwater turtle, Mauremys leprosa (Reptilia, Testudines, Geoemydidae). Zoologica Scripta 35: 97-108.

GODINHO, R., CRESPO, E.G., FERRAND, N. \& HARRIS, D.J. 2005. Phylogeny and evolution of the green lizards, Lacerta spp. (Squamata: Lacertidae) based on 
mitochondrial and nuclear DNA sequences. Amphibia-Reptilia 26: 271-286.

GOMEZ, A. \& LUNT, D.H. 2006. Refugia within refugia: patterns of phylogeographic concordance in the Iberian Peninsula. In: Phylogeography in Southern European Refugia: Evolutionary Perspectives on the Origin and Conservation of European Biodiversity, (eds) S. Weiss \& N. Ferrand. pp. 155-188. Springer, New York

GUICKING, D., JOGER, U. \& WINK, M. 2002. Molecular phylogeography of the viperine snake (Natrix maura) and the dice snake (Natrix tessellata): first results. Biota 3: 49-59.

GUICKING, D., LAWSON, R., JOGER, U. \& WINK, M. 2006. Evolution and phylogeny of the genus Natrix (Serpentes: Colubridae). Biological Journal of the Linnean Society 87: 127-143.

HARRIS, D.J., CARRANZA, S., ARNOLD, E.N., PINHO, C. \& FERRAND, N. 2002. Complex biogeographical distribution of genetic variation within Podarcis wall lizards across the Strait of Gibraltar. Journal of Biogeography 29(9): 1257-1262.

HARRIS, D.J., BATISTA, V. \& CARRETERO, M.A. 2004a. Assessment of genetic diversity within Acanthodactylus erythrurus (Reptilia: Lacertidae) in Morocco and the Iberian Peninsula using mitochondrial DNA sequence data. Amphibia-Reptilia 25: 227-232.

HARRIS, D.J., BATISTA, V., CARRETERO, M.A. \& FERRAND, N. 2004b. Genetic variation in Tarentola mauritanica (Reptilia: Gekkonidae) across the Strait of Gibraltar derived from mitochondrial and nuclear DNA sequences. Amphibia-Reptilia 25: 451-459.

HARRIS, D.J., BATISTA, V., LYMBERAKIS, P. \& CARRETERO, M.A. 2004c. Complex estimates of evolutionary relationships in Tarentola mauritanica (Reptilia: Gekkonidae) derived from mitochondrial DNA sequences. Molecular Phylogenetics and Evolution 30: 855-859.

HARRIS, D.J. \& FROUFE, E. 2005. Taxonomic inflation: species concept or historical geopolitical bias? Trends in Ecology and Evolution 20: 6-7.

HARRIS, D.J., VASCONCELOS, R. \& BRITO, J.C. 2007. Genetic variation within African spiny-tailed lizards (Agamidae: Uromastyx) estimated using mitochondrial DNA sequences. Amphibia-Reptilia 28: 1-6.

HEWITT, G. 2000. The genetic legacy of the Quaternary ice ages. Nature 405: 907-913.

HUEISENBECK, J.P. \& BOLLBACK, J.P. 2001. Empirical and hierarchical Bayesian estimation of ancestral states. Systematic Biology 50: 351-366.

HUELSENBECK, J.P. \& CRANDALL, K.A. 1997. Phylogeny estimation and hypothesis testing using maximum likelihood. Annual Review of Ecology and Systematics 28: 437-466.

HUELSENBECK, J.P. \& RONQUIST, F. 2001. MrBayes: Bayesian inference of phylogeny. Bioinformatics 17: 754-755.

MENDONÇA, B. \& HARRIS, D.J. 2007 Genetic variation within Trogonophis wiegmanni Kaup 1830. Belgian Journal of Zoology 137: 239-242.

MYERS, N., MITTERMEIER, R.A., MITTERMEIER, C.G., DA FONSECA, G.A.B. \& KENT, J. 2000. Biodiversity hotspots for conservation priorities. Nature 403: 853858 .
PAULO, O.S., PINTO, I., BRUFORD, M.W., JORDAN, W.C. \& NICHOLS, R.A. 2002. The double origin of Iberian peninsular chameleons. Biological Journal of the Linnean Society 75: 1-7.

PERERA, A., VASCONCELOS, R., HARRIS, D.J., BROWN, R.P., CARRETERO, M.A. \& PÉREZMELLADO, V. 2007. Complex patterns of morphological and mitochondrial DNA variation in Lacerta perspicillata (Reptilia; Lacertidae). Biological Journal of the Linnean Society 90: 479-490.

POSADA, D. \& CRANDALL, K.A. 1998. Modeltest: testing the model of DNA substitution. Bioinformatics 14: 817-818

PINHO, C., HARRIS, D.J. \& FERRAND, N. 2003. Genetic polymorphism of 11 allozyme loci in populations of wall lizards (Podarcis sp.) from the Iberian Peninsula and North Africa. Biochemical Genetics 41: 343-359.

PINHO, C., FERRAND, N. \& HARRIS, D.J. 2006. Reexamination of the Iberian and North African Podarcis (Squamata: Lacertidae) phylogeny based on increased mitochondrial DNA sequencing. Molecular Phylogenetics and Evolution 38: 266-273.

PINHO, C., HARRIS, D.J., FERRAND, N. 2007a. Contrasting patterns of population subdivision and historical demography in three western Mediterranean lizard species inferred from mitochondrial DNA variation. Molecular Ecology 16: 1191-1205.

PINHO, C., HARRIS, D.J. \& FERRAND, N. 2007b. Comparing patterns of nuclear and mitochondrial divergence in a cryptic species complex: the case of Iberian and North African wall lizards (Podarcis, Lacertidae). Biological Journal of the Linnean Society 91: 121-133.

RATO, C., BRITO, J.C., CARRETERO, M.A., LARBES, S., SHACHAM, B. \& HARRIS, D.J. 2007. Phylogeography and genetic diversity within Psammophis schokari (Psammophiinae) in North Africa based on mitochondrial DNA sequences. African Zoology 42: 112-117.

SAMBROOK, J., FRITSCH, E. F. \& MANIATIS, T. 1989. Molecular Cloning: A Laboratory Manual. Cold Spring Harbor Press, New York.

SOTIROPOULOS, K., ELEFTHERAKOS, K., DŽUKIĆ, G., KALEZIĆ, M.L., LEGAKIS, A. \& POLYMENI, R.M. 2007. Phylogeny and biogeography of the alpine newt Mesotriton alpestris (Salamandridae, Caudata), inferred from mtDNA sequences. Molecular Phylogenetics and Evolution 45(1): 211-226.

SWOFFORD, D.L. 2002. PAUP*: Phylogenetic Analysis Using Parsimony (and other methods) 4.0.b10. Sinauer Associates, Sunderland, Massachusetts.

THOMPSON, J.D., HIGGINS, D.G. \& GIBSON, T.J. 1994. Clustal W: improving the Nucleic Acid Research 22: 4673-4680.

VASCONCELOS, R. \& HARRIS, D.J. 2006. Phylogeography of the false smooth snakes, Macroprotodon - mtDNA sequences from Portugal confirm European populations arrived recently from Northwest Africa. Herpetozoa 19(12): 77-81.

VASCONCELOS, R., CARRETERO, M.A. \& HARRIS, D.J. 2006. Phylogeography of the genus Blanus (worm lizards) in Iberia and Morocco based on mitochondrial and nuclear markers - preliminary analysis. Amphibia-Reptilia 27: 339-346.

Responsible Editor: P. le F.N. Mouton 